\title{
Effects of air temperature, humidity and air pollution on fertility of birch pollen in urban environments
}

\author{
O.V. Bychkova, L.P. Khlebova \\ Altai State University, 61 Lenina prospect, Barnaul, 656049, Russia. \\ E-mail: olga4ka asu@mail.ru, hlebova61@mail.ru
}

Received: 14.08.2019. Accepted: 26.09.2019

\begin{abstract}
We studied effects of environmental factors on pollen fertility of Betula pendula Roth.) in 15 sites of the city of Barnaul (Russia, Altai Territory), differing in traffic intensity. We found that low temperature was more stressful for the development of birch pollen compared to high one. When the temperature drops below $+8^{\circ} \mathrm{C}$, the amount of sterile pollen in all locations significantly increased regardless of the anthropogenic load, on average exceeding $8 \%$. With an increase in temperature of more than $+10{ }^{\circ} \mathrm{C}$, the proportion of sterile pollen also increased, but the jump was not as sharp as in cold weather. The optimum temperature for the formation of fertile pollen grains was in the range of $8-10^{\circ} \mathrm{C}$. The optimal humidity for the development of fertile pollen of $\mathrm{B}$. pendula was $40-45 \%$. The increase in air dryness led to a significant decrease in the quality of pollen grains, the proportion of sterile ones exceeded $8 \%$. According to the transmission coefficient (Keff $=0.1514$ ), the dominant factor in the development of sterile pollen grains of birch was the level of air pollution (concentration of carbon monoxide). Air temperature (Keff $=0.1427$ ) and humidity (Keff $=0.1427$ ) affected equally the quality of pollen. The proposed model makes it possible to predict the level of sterile birch pollen in the conditions of Barnaul depending on the weather conditions of vegetation and on the level of pollutants in the atmosphere.
\end{abstract}

Key words: Betula pendula Roth.; Pollen sterility; Pollution; Carbon monoxide; Air temperature; Humidity; Information statistics

\section{Introduction}

Air is one of the leading indicators of the environment, since it directly affects its quality. In addition to global climate change, the environment is largely susceptible to numerous harmful effects that alter the composition of air (Bytnerowicz et al., 2007; GhoraniAzam et al., 2016). Air pollution in urban areas consists of the influx of harmful substances from stationary and mobile sources, the most significant of which are industrial enterprises, transport and domestic heating. The most common harmful substances in the air are gases such as carbon monoxide (CO), sulfur dioxide $\left(\mathrm{SO}_{2}\right)$, nitrogen dioxide $\left(\mathrm{NO}_{2}\right)$ and suspended soot microparticles, as well as specific chemical elements ( $\mathrm{Pb}, \mathrm{Cd}, \mathrm{Mn}, \mathrm{As}, \mathrm{Ni}, \mathrm{Cr}, \mathrm{Zn}$ and other heavy metals) and organic compounds (Batos et al., 2019). Pollution directly or indirectly damages the genetic material of plants, animals and humans (Chehregani et al., 2004). Environmental degradation due to anthropogenic impact has led to the search for suitable methods for assessing the state of the environment. They should be informative, easy to use and cost-effective. One of these methods is bioindication, including phytoindication. Phytoindication methods allow us to assess changes in environmental quality in accordance with the response of plants (Onete et al., 2010). Tree plantations are one of the mechanisms for stabilizing the ecological situation in urban environments. They remove harmful pollutants from the air by precipitating them on the surfaces or depositing them in the tissues (Samecka-Cymerman et al., 2011; Nowak et al. 2014; Stojnić et al., 2019). During their long life cycle, plants accumulate a significant amount of harmful substances that cause numerous structural and physiological changes and disrupt the normal functioning of the plant body. (Cuinica et al., 2014; El Khatib et al., 2016). The response of plants to environmental stress is genetically determined and reflects the competitiveness, adaptive capabilities and resistance to adverse effects of natural and anthropogenic factors in various species.

Over the past decades, palynological methods have been actively introduced into the practice of bio-indicator assessments of various territories (Tret'yakova and Noskova, 2004; Mišík et al., 2007; Gottardini et al., 2008; Dušička et al., 2013; Cuinica et al., 2014; Khlebova and Bychkova, 2016). Available literature is devoted to various aspects of the development of pollen grains. However, one should take into account the lack of sufficiently accurate data on the pollen research methodology, which complicates pollen analysis (Kedves et al., 2002). The possible adaptation of plants to certain toxins is the main disadvantage of this method. Some physiological characteristics (unknown duration of exposure to the substance, environmental conditions affecting pollen development, short viability and productivity only for a fixed period) are unfavorable for its use as an indicator in in situ conditions (Gregušková and Mičieta, 2013). High pollen sensitivity during development causes a reaction to extreme environmental conditions, such as heat and dryness. On the other hand, pollen can accumulate harmful substances and provide information about their negative effects. Even small changes in the pollen genome can cause damage to plants and, consequently, a decrease in fertility. In addition to the genotoxic effects of emissions from traffic (Calzoni et al., 2006; Carneiro et al., 2011), the pollen test was also used to assess the genotoxic hazard in areas with increased radioactivity (Mičieta and Murín, 2007), for bioindication of pollution air near industrial zones and landfills (Mišík et al., 2007), as well as to detect the genotoxicity of an environment contaminated with heavy metals (Gorbov et al., 2015). Despite numerous studies, the influence of various factors on the pollen sterility in woody plants has not been adequately evaluated. The material presented is mostly fragmentary. Some authors highlight the influence of two factors (conditions of the year and genotype) on pollen fertility (sterility) (Storme and Geelen, 2014; Ejsmond et al., 2015), while others believe that weather and pollutants influence its viability (Tret'yakova and Noskova, 2004; Chakrabarti et al., 2011; Jóźwiak and Jóźwiak, 2014; Kudryavs'ka and Dichko, 2014). The aim of the work was to evaluate and to compare the factors affecting the formation and functioning of the male gametophyte of birch (Betula pendula Roth.) in an urban environment. 


\section{Materials and Methods}

The object of the study was $B$. pendula, which grows in the city of Barnaul (Russia, Altai Territory) (Figure 1A). The city is located in the south of Western Siberia, in the northeast of the Priobsk plateau, on the left bank of the Ob River at the confluence of the Barnaulka River with the Ob. The climate is sharply continental with moderately severe and light snowy winters and warm summers. The coldest month is January $\left(-17.5^{\circ} \mathrm{C}\right)$, the warmest month is July $\left(+19.8^{\circ} \mathrm{C}\right)$. The annual precipitation is $477 \mathrm{~mm}$. Barnaul is a major transport hub, the West Siberian Railway passes through it. Highways connect the city with the settlements of the region, as well as with Novosibirsk, Kuzbass, Kazakhstan. The city has a river port. Public green spaces occupy an area of 228 hectares. $B$. pendula is one of the most hardy native tree species. It has a wide ecological amplitude and grows from the moist forests of the upper belt of the Altai Mountains to the steppes of the flat part of the Altai Territory, bordering Kazakhstan. The birch is suitable for all types of forest protection breeding and is widely used in landscaping the city of Barnaul. Pollen samples were collected in three districts of the city (Leninsky, Zheleznodorozhny, Central). Sampling locations were distributed along the main highways with heavy traffic (Lenin Ave., Krasnoarmeysky Ave., Stroiteley Ave., Cosmonavtov Ave.). Several territories were located in residential areas with less traffic load (Solnechnaya Polyana St., Shukshin St.), as well as near a busy road, but protected by residential multi-storey buildings (133 Krasnoarmeysky Ave.). We explored 15 sites throughout the city. The choice of sites is due to the fact that vehicles are among the largest sources of air pollution, and their emissions contain about 200-400 chemical compounds with toxic effects. The control was conditionally "clean" area, located in a forest near the South Siberian Botanical Garden (25 Lesosechnaya St.).

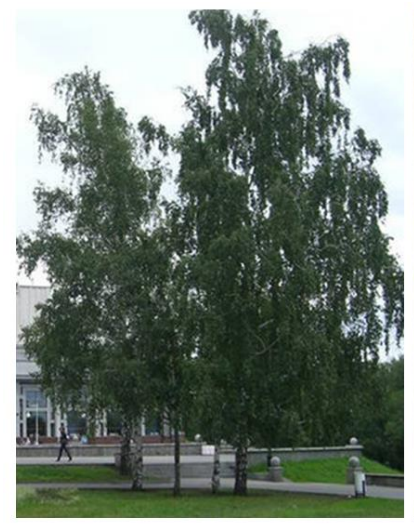

A

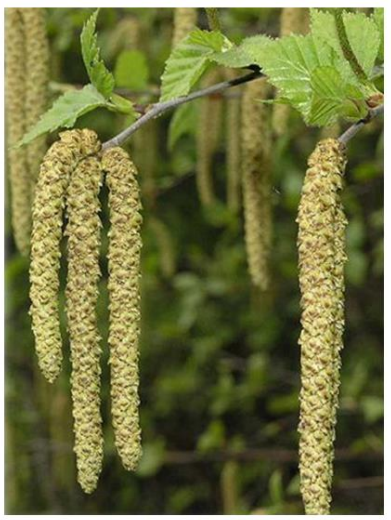

$\mathbf{B}$

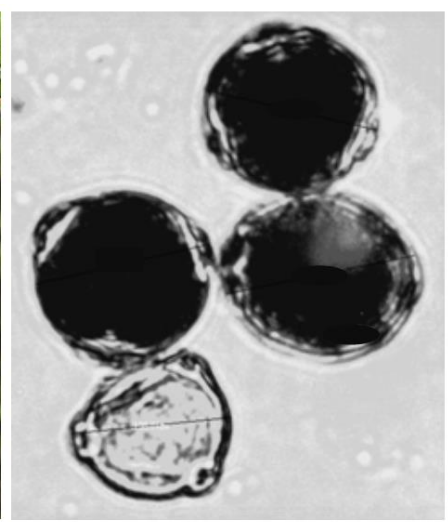

C

Figure 1. Betula pendula Roth.: A - typical trees; B - male inflorescences; C - fertile (painted) pollen, sterile (unpainted) pollen.

Male inflorescences with pollen were taken in 2015-2017 during the period of the full bloom (last decade of April - first decade of May depending on the year) from trees without visible damage by pests and phytopathogens, $25-30 \mathrm{~cm}$ in diameter, growing in groups of at least 5 trees (Figure 1B). Inflorescences were collected in the lower third of the outer part of the crown from a height of 2-2.5 $\mathrm{m}$ in all four directions, 10 pcs. from each branch. Sampling was done in the morning for 3 days with no wind and rain. After drying at a temperature of $+30 \pm 1{ }^{\circ} \mathrm{C}$ for $48 \mathrm{~h}$, pollen was stored in a desiccator with $\mathrm{CaCl}_{2}$ in a refrigerator at $+5 \pm 1{ }^{\circ} \mathrm{C}$. $\mathrm{A}$ cytological analysis of pollen was performed under the Olympus BX-S1 microscope at a magnification of $10 \times 15 \times 40$. Cytological preparations were made according to generally accepted methods. A drop of the solution and a small amount of pollen were placed on a glass slide, covered with a coverslip and analyzed under a microscope (Pausheva, 1988). The pollen quality was determined by the accumulation of starch in the cytoplasm by the reaction of staining it with Lugol's iodine solution. Only fertile pollen got stained with iodine, while pollen which did not get stained was sterile one (Figure 1C). In each field of view, the amount of painted as well as unpainted pollen was counted. Two thousand pollen grains from each location in four replicates were estimated. Sterility percentage of pollen was calculated from total number of pollen grains and a number of sterile pollen. At the sampling sites, air pollution was monitored by vehicle exhaust emissions by calculating the density of automobile flux. Air pollution by exhaust gases of automobiles was calculated by the formula for estimating the concentration of carbon monoxide in $\mathrm{mg}^{\prime} \mathrm{m}^{3}$ (Fedorova and Nikol'skaya, 2001). ANOVA analysis of the data received was carried out using the Microsoft Excel 2010 software package. Mathematical analysis of the results was carried out using the logical information method (Puzachenko and Moshkin, 1969).

\section{Results and Discussion}

Pollen quality is an important factor in the process of fertilization and seed formation in anemophilous plants. One of its indicators is the availability of nutrients necessary for the growth of pollen tubes and the fertilization functions of male gametes. Lack of nutrients, in particular starch, determines pollen sterility. Table 1 presents the proportion of sterile pollen of $B$. pendula growing in different sites of the city of Barnaul. In 2015, the average value of the trait was $4.28 \%$, which significantly differed from the control value of $2.06 \%$. A maximum of sterile pollen, 4.5 times higher than the control, was found in a sample taken at Pobeda Sq. (9.17\%). The minimum quantity (at the control level) was at 133 Krasnoarmeysky Ave. (1.62\%).

Table 1. Pollen sterility of Betula pendula Roth.) at sampling sites in Barnaul (Altai Territory, Russia) in 2015-2017.

\begin{tabular}{llll}
\hline Locality & \multicolumn{2}{l}{ Pollen sterility, \% } & \\
& $\mathbf{2 0 1 5}$ & $\mathbf{2 0 1 6}$ & $\mathbf{2 0 1 7}$ \\
133 Krasnoarmeysky Ave. & $1.62 \pm 0.18$ & $3.43 \pm 0,36$ & $2.69 \pm 0.30^{*}$ \\
96a Krasnoarmeysky Ave. & $2.09 \pm 0.30$ & $5.92 \pm 0.77^{*}$ & $3.30 \pm 0.36^{*}$ \\
46 Molodezhnaya St. & $2.34 \pm 0.25$ & $8.69 \pm 2.18^{*}$ & $11.10 \pm 0.26^{*}$ \\
37 Dzerzhinsky St. & $2.14 \pm 0.27$ & $4.54 \pm 0.52^{*}$ & $2.32 \pm 0.37^{*}$ \\
17 Solnechnaya Polyana St. & $2.63 \pm 0.24$ & $5.11 \pm 0.27^{*}$ & $2.08 \pm 0.33$ \\
98 Krasnoarmeysky Ave. & $5.17 \pm 0.39 *$ & $5.60 \pm 1.57^{*}$ & $3.54 \pm 0.41^{*}$ \\
36 Krasnoarmeysky Ave. & $5.50 \pm 0.39^{*}$ & $4.64 \pm 0.94 *$ & $3.08 \pm 0.34^{*}$ \\
\hline
\end{tabular}




\begin{tabular}{llll}
\hline 10 Shukshin St. & $4.02 \pm 0.66$ & $3.39 \pm 0.61^{*}$ & $2.76 \pm 0.49^{*}$ \\
67 Lenin Ave. & $5.83 \pm 0.34^{*}$ & $10.72 \pm 1.00^{*}$ & $3.44 \pm 0.33^{*}$ \\
104 Krasnoarmeysky Ave. & $4.26 \pm 0.21^{*}$ & $8.72 \pm 1.01^{*}$ & $3.67 \pm 0.76^{*}$ \\
12 Cosmonavtov Ave. & $6.46 \pm 0.28^{*}$ & $7.64 \pm 1.09^{*}$ & $3.89 \pm 0.54^{*}$ \\
53 Lenin Ave. & $6.48 \pm 0.31^{*}$ & $9.17 \pm 2.44^{*}$ & $4.05 \pm 0.47^{*}$ \\
135 Krasnoarmeysky Ave. & $4.50 \pm 0.20^{*}$ & $9.37 \pm 2.95^{*}$ & $3.68 \pm 0.63^{*}$ \\
Pobeda Sq. & $9.17 \pm 5.97^{*}$ & $19.01 \pm 3.76^{*}$ & $11.24 \pm 0.21^{*}$ \\
25 Lesosechnaya St. (Control) & $2.06 \pm 0.53$ & $2.25 \pm 0.38$ & $1.74 \pm 0.26$ \\
\hline
\end{tabular}

Note: Data are in the form of mean \pm SEM; * - Differences with control are significant at $\mathrm{P}<0.05$

The conditions of 2016 turned out to be significantly less favorable for the formation of high-quality pollen. The average value of sterile pollen grains in comparison with the previous year increased almost 2 times and amounted to $7.21 \%$. All samples contained sterile pollen in excess of control. The largest proportion still found at Pobeda Sq., reaching 19.01\%. In 2017, the average content of unpainted pollen corresponded to the level of 2015 (4.17\%). However, the variability of the trait was significantly higher and ranged from 2.69 (133 Krasnoarmeysky Ave.) to 11.24\% (Pobeda Sq.). The sterility of birch pollen in the control location showed a minimum value among the studied years $(1.74 \%)$.

The level of sterile pollen is an integral indicator reflecting various violations of the spermatogenesis process and the number of microsporocytes that have not passed natural selection. Some of these disorders, of course, are the result of internal failures of the plant metabolism process and are related to spontaneous mutations, and some are induced anomalies due to external factors, including technogenic ones. Comparison of the experimental territories with the control indicator obtained in favorable environmental conditions will make it possible to isolate background pollution and identify technogenic ones. In our study, in areas that differ in the level of transport load, birch pollen with a different level of sterility is formed. Thus, the sterility of birch pollen in the conditions of the city of Barnaul is a fairly informative indicator for the separation of different territories according to the level of environmental pollution. Analysis of variance confirmed the validity of the influence of the "Location" factor on the variability of the trait (Table 2).

Table 2. Results of ANOVA analysis of the quality of birch pollen (Betula pendula Roth.) in Barnaul (Altai Territory, Russia) in 2015$2017, \%$.

\begin{tabular}{lllll}
\hline Source of variation & SS & df & mS & F \\
Location & 1248,24 & 14 & 89,16 & $26,38^{* *}$ \\
Year & 356,56 & 2 & 178,28 & $52,74 * *$ \\
Location $\times$ Year Interaction & 454,72 & 28 & 16,24 & $4,80 * *$ \\
Error & 456.3 & 135 & 3,38 & \\
\hline Note: $* *-\mathrm{P}<0.01$ & & & &
\end{tabular}

The formation of pollen grain quality is influenced by a complex of factors of exogenous and endogenous nature. Each factor individually and their totality form a phenotype in a plant that is most adapted to living conditions. Under natural conditions, it is practically impossible to assess the effect of the whole complex of factors affecting plants. It is most convenient to consider the action of each of the factors separately. We found that the contribution of various factors to the formation of sterile birch pollen in the conditions of the city of Barnaul was different. The influence of the "Location" factor reached 49.6\%, the proportion of the conditions of the year was the smallest and amounted to $14.17 \%$, while the interaction of these factors was $18.08 \%$ (Figure 2 ).
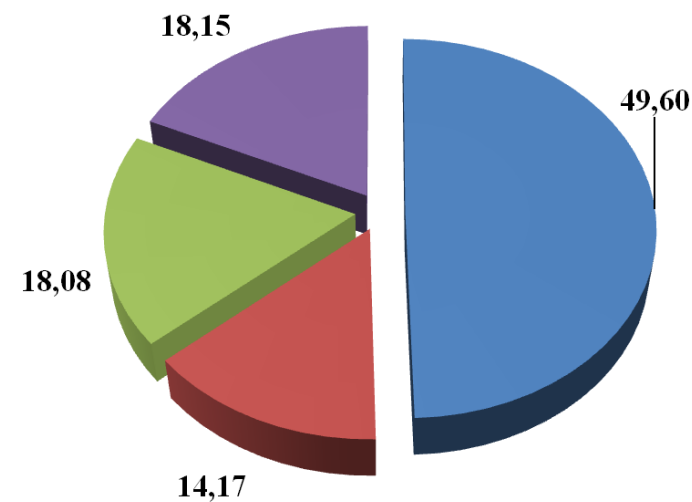

\author{
- Location \\ Year \\ Location x Year Interaction \\ Error
}

Figure 2. The effects of various factors on the development of sterile pollen in Betula pendula Roth. under conditions of the city of Barnaul (Altai Territory, Russia) in 2015-2017, \%.

Let us consider in more detail the influence of various climatic factors on the development of birch pollen. In our study, to assess the degree of influence of environmental factors on the development of birch pollen, a technique based on the methods of information statistics was applied. Information statistics are based on an estimate of the amount of information transmitted, expressed in terms of uncertainty, entropy of a factor and a phenomenon (measure of diversity). The use of the logical information method made it possible to isolate the action of individual factors and evaluate each individually. The degree of connection between the factor and the phenomenon (the presence of sterile pollen) was estimated using the information transfer coefficient ( $\boldsymbol{K}_{\text {eff }}$ ), and the most probable states of the function (the amount of sterile pollen) for a certain state of factors was estimated by the ratio of conditional probabilities ( $\boldsymbol{k}$ ) (Puzachenko and Moshkin, 1969). The climatic characteristics of Barnaul are variable. There are years with sharp fluctuations in temperature and humidity from maximum to minimum. Temperature conditions throughout the year affect plants. However, the main attention in identifying the relationship between pollen quality and the thermal factor was given to the temperature parameters for April and May (the birch bloom period in the Altai Territory). A comparative analysis of air temperature over the last decade of April and the first decade of May and the proportion of sterile pollen in various locations of the city over three years revealed the following pattern. Low temperature was more stressful for the development of birch pollen compared to 
high one. When the temperature dropped below $+8{ }^{\circ} \mathrm{C}$, the amount of sterile pollen in all locations significantly increased regardless of the anthropogenic load, exceeding $8 \%$. The optimum temperature for the formation of pollen grains with a high content of nutrients (fertile pollen) was a temperature in the range of $8-10{ }^{\circ} \mathrm{C}$. Pull of sterile pollen grains does not exceed $2 \%$. With an increase in temperature of more than $+10^{\circ} \mathrm{C}$, the proportion of sterile pollen also increased, but the jump was not as sharp as in cold weather. (Figure 3, left).
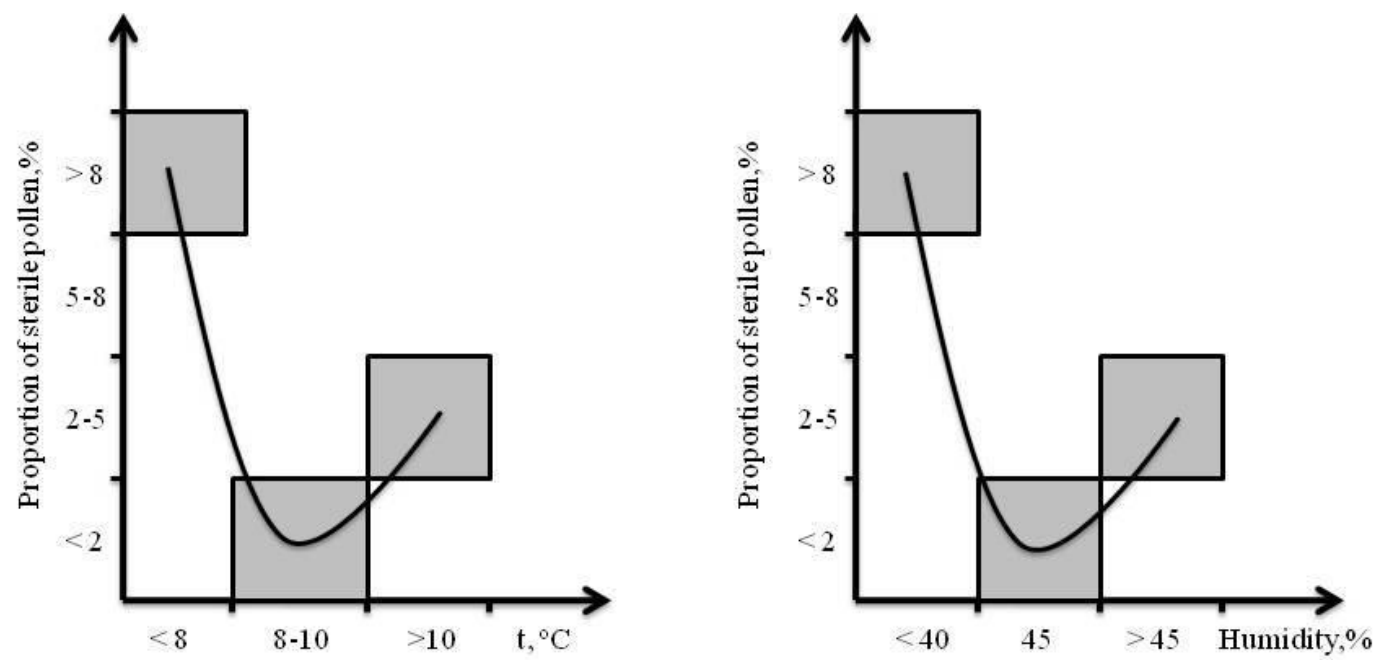

Figure 3. The effects of air temperature (left) and air humidity (right) on the amount of sterile pollen of birch Betula pendula Roth. in the conditions of the city of Barnaul (Altai Territory, Russia) in 2015-2017.

Since plant productivity is determined not only by air temperature, but also, to a large extent, by its humidity, we analyzed the influence of this factor on the pollen formation process. The trend in the development of sterile pollen due to the influence of relative humidity was the following. The minimum amount of sterile pollen (less than $2 \%$ ) was formed at $40-45 \%$ humidity during the bloom of birch. The increase in air dryness (humidity below $40 \%$ ) led to a significant decrease in the quality of pollen grains, the proportion of sterile ones exceeded $8 \%$. With a change in humidity to a level exceeding $45 \%$, a smooth growth of non-viable pollen to $5 \%$ was observed (Figure 3, right). Thus, the optimal conditions for the development of fertile pollen of $B$. pendula, which grows in various locations of the city of Barnaul under different anthropogenic loads, are air temperature of $8-10^{\circ} \mathrm{C}$ at a relative humidity of $40-45 \%$. Based on the available data on the concentration of carbon monoxide in pollen sampling locations, we established a direct dependence of the amount of sterile birch pollen on the CO coefficient $\left(\boldsymbol{K}_{\boldsymbol{c o}}\right)$ (Figure 4). A sufficiently high ratio of conditional probabilities $(\boldsymbol{k})$ indicates that with an increase in the content of carbon monoxide in the air, the fraction of pollen unsuitable for fertilization increases. The maximum fertile pollen level was formed when the carbon monoxide content in the air was below 20 mg/ $\mathrm{m}^{3}$. With an increase in CO concentration to $60 \mathrm{mg} / \mathrm{m}^{3}$, a significant increase in the level of sterile pollen was revealed.

According to the transmission coefficient, the dominant factor in the development of sterile pollen grains of birch is the level of air pollution in the growing area of this species $\left(\boldsymbol{K}_{\text {eff }}=0.1514\right)$. Air temperature $\left(\boldsymbol{K}_{\text {eff }}=0.1427\right)$ and humidity $\left(\boldsymbol{K}_{\text {eff }}=0.1427\right)$ affect equally the quality of pollen. An analysis of the data using the logical information method confirms the above two-way analysis of variance, which indicates the maximum contribution to the variability of pollen quality of the "Location" factor. The districts of the city where pollen samples were taken differed in traffic loads, and, consequently, in the emission of carbon monoxide into the atmosphere.

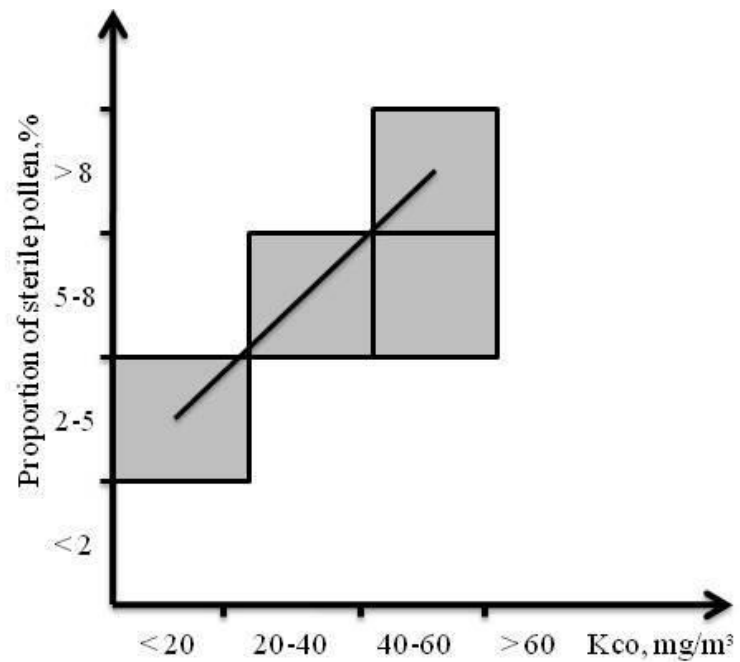

Figure 4. Effect of carbon monoxide concentration on the amount of sterile pollen of Betula pendula Roth. in the conditions of the city of Barnaul (Altai Territory, Russia) in 2015-2017.

Thus, the proposed model makes it possible to predict the level of sterile birch pollen in the conditions of Barnaul depending on the weather conditions of vegetation and the level of pollutants in the atmosphere. 


\section{Conclusion}

Based on the results of logical information analysis, we found that low temperature was more stressful for the development of birch pollen compared to high one. When the temperature drops below $+8{ }^{\circ} \mathrm{C}$, the amount of sterile pollen in all locations significantly increased regardless of the anthropogenic load, on average exceeding $8 \%$. With an increase in temperature of more than $+10{ }^{\circ} \mathrm{C}$, the proportion of sterile pollen also increased, but the jump was not as sharp as in cold weather. The optimum temperature for the formation of fertile pollen grains was a temperature in the range of $8-10{ }^{\circ} \mathrm{C}$. The optimal humidity for the development of fertile pollen of $B$. pendula was $40-45 \%$. The increase in air dryness led to a significant decrease in the quality of pollen grains, the proportion of sterile ones exceeded $8 \%$. According to the transmission coefficient $\left(\boldsymbol{K}_{\text {eff }}=0.1514\right)$, the dominant factor in the development of sterile pollen grains of birch was the level of air pollution (concentration of carbon monoxide). Air temperature ( $\boldsymbol{K}_{\text {eff }}$ $=0.1427)$ and air humidity $\left(\boldsymbol{K}_{\text {eff }}=0.1427\right)$ affected equally the quality of pollen. The proposed model makes it possible to predict the level of sterile birch pollen in the conditions of Barnaul depending on the weather conditions of vegetation and the level of pollutants in the atmosphere.

\section{Conflict of Interest}

The authors declare that they have no conflict of interests.

\section{References}

Batos, B., Veselinović, M., Rakonjac, L., \& Miljković, D. (2019). Morphological properties of pollen as bioindicators of deciduous woody species in belgrade parks (Serbia). Poplar, 203, 19-30.

Bytnerowicz, A., Omasa, K., \& Paoletti, E. (2007). Integrated effects of air pollution and climate change on forests: A northern hemisphere perspective. Environmental Pollution, 147, 438-445. DOI: 10.1016/j.envpol.2006.08.028

Calzoni, G. L., Antognmišík, M., Solenská, M., Mičieta, K., Mišíková, K., \& Knasmüller, S. (2006). In situ monitoring of clastogenicity of ambient air in Bratislava, Slovakia using the Tradescantia micronucleus assay and pollen abortion assays. Mutat. Res., 605, 1. DOI:10.1016/j.mrgentox.2005.12.009

Carneiro, M. F. H., Ribeiro, F. Q., Fernandesfilho, F. N., Lobo, D. J. A., Barbosa, Jr. F., Rhoden, C. R., Mauad, T., Saldiva, P. H. N., \& Carvalhooliveira, R. (2011). Pollen abortion rates, nitrogen dioxide by passive diffusive tubes and bioaccumulation in tree barks are effective in the characterization of air pollution. Environ. Exp. Bot., 72, 272. DOI: org/10.1016/j.envexpbot.2011.04.001

Chakrabarti, B., Singh, S. D., Nagarajan, S., \& Aggarwal, P. K. (2011). Impact of temperature on phenology and pollen sterility of wheat varieties. Australian Journal of Crop Science, 5(8), 1039-1043.

Chehregani, A. H., Majde, A., Moin, M., Golami, M. M., Shariatzadeh, M., \& Mohsenzae, F. (2004). Effect of air pollution on some cytogenetic characteristics, structure, viability and proteins of Zinnia elegans pollen grains. Pakistan Journal of Biological Sciences, 7(1), 118-122. doi:10.3923/pjbs.2004.118.122

Cuinica, L. G., Abreu, I., \& Esteves da Silva, J. (2014). Effect of air pollutant $\mathrm{NO}_{2}$ on Betula pendula, Ostrya carpinifolia and Carpinus betulus pollen fertility and human allergenicity. Environmental Pollution, 186, 50-55.

Dušička, J., Mičieta, K., Brutovska, E., Samelova, A., \& Ščevkova, J. (2013). Aeropalynological aspects in the detection of the quality of air in Bratislava. Ekologia (Bratislava), 32, 1, 39-53. doi:10.2478/eko-2013-0004

Ejsmond, M. J., Ejsmond, A., Banasiak, Ł., Karpin' ska-Kołaczek, M., Kozłowski, J., \& Kołaczek, P. (2015). Pollen at high temperature: an adaptation to increased competition on the stigma? Plant Ecology, 216, 1407-1417. DOI: 10.1007 / s11258-0150519-z

El-Khatib, A. A., El-Shanawany, A. A., \& El-Amery, E. M. (2016). Urban tree leaf as bioindicator for air pollution around superphosphate fertilizers plant, Upper Egypt. Journal of Ecology of Health \& Environment, 4(2), 95-101.

Fedorova, A. I., \& Nikol'skaya, A. N. (2001). Praktikum po ehkologii i okhrane okruzhayushchej sredy [Workshop on ecology and environmental protection], Moscow, Vlados Publ. (in Russian).

Ghorani-Azam, A., Riahi-Zanjani, B., \& Balali-Mood, M. (2016). Effects of air pollution on human health and practical measures for prevention in Iran. J. Res. Med. Sci., 21, 65. DOI: 10.4103 / 1735-1995. 189646

Gorbov, S. N., Bezuglova, O. S., Varduni, T. V., Gorovcov, A. V., Tagiverdiev, S. S., \& Gil'debrant, Yu. A. (2015). Genotoksichnost' i zagryaznenie tyazhelymi metallami estestvennyh i antropogenno-preobrazovannyh pochv Rostova-na-Donu. Pochvovedenie, 12, 1519. (in Russian).

Gottardini, E., Cristofori, A., Cristofolini, F., Maccherini, S., \& Ferretti M. (2008). Ambient levels of nitrogen dioxide ( $\mathrm{NO}_{2}$ ) may reduce pollen viability in Austrian pine (Pinus nigra Arnold) trees - Correlative evidence from a field study. Science of the Total Environment, 402, 2-3, 299-305.

Gregušková, E., \& Mičieta, K. (2013). Phytoindication of the ecogenotoxic effects of vehicle emissions using pollen abortion test with native flora. Polish Journal of Environmental Studies, 22, 4, 1069-1076.

Jóźwiak, M. A., \& Jóźwiak, M. (2014). Bioindication as challenge in modern environmental protection. Eco/Chem Eng S., 21(4), 577591. DOI: https://doi.org/10.1515/eces-2014-0041

Kedves, M., Pardutz, A., \& Varga, B. (2002). Experimental investigations of the pollen grains of Quercus robur L. Taiwania, 47(1), 43-53. DOI : 10.6165 / tai.2002.47(1).43

Khlebova, L. P., \& Bychkova, O. V. (2016). Development of Pinus sy/vestris L. male gametophyte in urban environment. Biological Bulletin of Bogdan Chmelnitskiy Melitopol State Pedagogical University, 1, 390-408. (in Russian).

Kudryavs'ka, T. B., \& Dichko, A. O. (2014). Metod ocenki ta prognozuvannya vplivu tehnogennogo zabrudnennya na povetrya urboekosistemi. Vostochno-Evropeiskii zhurnal peredovyh tehnologii, 1/10 (67), 4-7. (in Ukraine).

Mičieta, K., \& Murín, G. (2007). Wild plant species in bio-indication of radioactive-contaminated sites around Jaslovské Bohunice nuclear power plant in the Slovak Republic. Journal of Environmental Radioactivity, 93, 26. DOI:10.1016 / j. jenvrad.2006.11.006

Mišík, M., Mičieta, K., Solenská, M., Mišíková, K., Pisarčíková, H., \& Knasmüller, S. (2007). In situ biomonitoring of the genotoxic effects of mixed industrial emissions using the Tradescantia micronucleus and pollen abortion tests with wild life plants: Demonstration of the efficacy of emission controls in an eastern European city. Environmental Pollution, 145, 459. DOI:10.1016 / j. envpol.2006.04.026

Nowak, D. J., Hirabayashi, S., Bodine, A., \& Greenfield, E. (2014). Tree and forest effects on air quality and human health in the United States. Environmental Pollution, 193, 119-129. DOI: 10.1016/j.envpol.2014.05.028

Onete, M., Pop, O. G., \& Gruira, R. (2010). Plants as indicators of environmental conditions of urban spaces from central parks of Bucharest. Environmental Engineering and Management Journal, 9(12), 1637-1645. DOI: 10.30638 / eemj.2010.225 
Pausheva, Z. P. (1988). Praktikum po tsitologii rastenij [Practical course on plant cytology]. Moscow, Agropromizdat Publ. (in Russian).

Puzachenko, Yu. G., \& Moshkin, A. V. (1969). Informationlogical analysis in medical-geographical studies. Itogi nauki. Meditsinskaya geografiya, 3, 5-74. (in Russian).

Samecka-Cymerman, A., Kolon, K., \& Kempers, A. (2011). Taxus baccata as a bioindicator of urban environmental pollution. Polich Journal of Environmental Studies, 20(4), 1021-1027.

Stojnić, S., Kebert, M., Drekić, M., Galić, Z., Kesić, L., Tepavac, A., \& Orlović, S. (2019). Heavy metals content in foliar litter and branches of Quercus petraea (Matt.) Liebl. and Quercus robur L. observed at two icp forests monitoring plots. Southeast Eur for, 10(2): early view. DOI:https://doi.org/10.15177/seefor.19-11

Storme, N. D., \& Geelen, D. (2014). The impact of environmental stress on male reproductive development in plants: biological processes and molecular mechanisms. Plant, Cell and Environment, 37, 1-18. DOI: 10.1111/pce.12142

Tret'yakova, I. N., \& Noskova, N. E. (2004). Pyl'ca sosny obyknovennoi v usloviyah ekologicheskogo stressa. Ekologiya, 1, 26. (in Russian).

\section{Citation:}

O.V. Bychkova, L.P. Khlebova (2019). Effects of air temperature, humidity and air pollution on fertility of birch pollen in urban environments. Ukrainian Journal of Ecology, 9(3), 346-351.

(cc) $\mathrm{EY}$ This work is licensed under a Creative Commons Attribution 4.0. License 